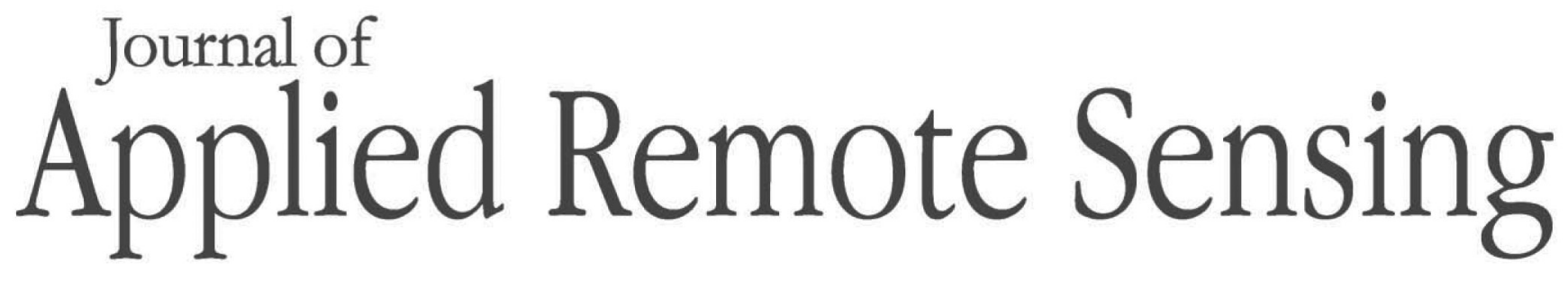

\title{
Validation of MERIS bio-optical products with in situ data in the turbid Lithuanian Baltic Sea coastal waters
}

Diana Vaičiūtè

Mariano Bresciani

Martynas Bučas 


\title{
Validation of MERIS bio-optical products with in situ data in the turbid Lithuanian Baltic Sea coastal waters
}

\author{
Diana Vaičiūtė, ${ }^{\mathrm{a}}$ Mariano Bresciani, ${ }^{\mathrm{b}}$ and Martynas Bučas ${ }^{\mathrm{a}}$ \\ aKlaipeda University, Coastal Research and Planning Institute, H. Manto 84, LT 92294, \\ Klaipeda, Lithuania \\ diana@corpi.ku.lt \\ ${ }^{b}$ Optical Remote Sensing Group, CNR-IREA, Via Bassini 15, 20133 Milano, Italy
}

\begin{abstract}
In this study bio-optical water quality indicators, chlorophyll $a$, colored dissolved organic matter (CDOM), and total suspended matter (TSM) were derived from the EnvisatMERIS satellite data and were compared with in situ measurements collected in the Lithuanian optically Case 2 coastal waters of the Baltic Sea. Eight MERIS full-resolution Level $1 \mathrm{~b}$ images, acquired during late spring and summer 2010, were processed using five, neural network-based processors for optically Case 2 or coastal and inland waters: FUB, C2R, Eutrophic, Boreal, and standard MERIS Level 2. Results showed that the FUB processor provided the most accurate estimates of the concentration of chlorophyll $a\left[R^{2}=69 \%\right.$; mean absolute error(MAE) $=$ $\left.7.76 \mathrm{mg} / \mathrm{m}^{3}\right]$ and TSM $\left(R^{2}=89 \%\right.$; MAE $\left.=3.93 \mathrm{~g} / \mathrm{m}^{3}\right)$. In situ CDOM absorption was most accurately estimated using the Boreal processor $\left(R^{2}=69 \%\right.$; MAE $\left.=0.201 / \mathrm{m}\right)$. We analyzed the factors that were most influential in explaining the differences in the accuracy and found that the Secchi depth and the sampling time were the most important factors. The greatest differences between satellite-derived and in situ values of water quality indicators were in correspondence with the lowest Secchi depth, suggesting that the plume zone created by freshwater coming from the hyper-eutrophic lagoon was the most sensitive region for the validation. The evident match between in situ measurements and satellite-based estimates was observed when field measurements were acquired $1-2 \mathrm{~h}$ before to approximately $2-4 \mathrm{~h}$ after the satellite overpass. Results of this validation work confirmed that remote sensing techniques are suitable for monitoring the changes of optical constituents in Lithuanian coastal waters. ( 2012 Society of Photo-Optical Instrumentation Engineers (SPIE). [DOI: 10.1117/1.JRS.6.063568]
\end{abstract}

Keywords: optically active components; remote sensing; MERIS; Baltic Sea.

Paper 12020 received Jan. 23, 2012; revised manuscript received Jul. 12, 2012; accepted for publication Jul. 25, 2012; published online Sep. 12, 2012.

\section{Introduction}

The Baltic Sea is one of the largest, semi-enclosed, brackish seas in the world. ${ }^{1}$ Salinity balance is maintained by outflow of rivers and precipitation at the surface layer and by a variable nearbottom inflow of higher salinity water through the Danish Straits. The surface salinity decreases from 6 to 8 PSU in the Baltic Proper, to 5-6 PSU in the Bothnian Sea and 2-3 PSU in the Bothnian Bay. Moreover, the large freshwater content is strongly associated with nutrient input from the densely populated and intensively cultivated catchment areas and the atmosphere. ${ }^{2}$ The excess of the nutrients is one of the major causes for the eutrophication processes occurring in the sea. The turbid fresh water plumes with river-borne nutrients and pollution in the Baltic Sea can be detected by three optical water components: colored dissolved organic matter, ${ }^{3}$ total suspended matter ${ }^{4}$ and chlorophyll $a .^{5}$

Chlorophyll $a(\mathrm{chl} a)$ is the main photosynthetically active pigment of phytoplankton, commonly used as a proxy for the microalgae biomass in the water. ${ }^{6}$ The concentration of $\operatorname{chl} a$ is influenced by various factors such as water temperature and water nutrient content. ${ }^{7-10}$ In fact, the massive blooms of primary producers, especially potential toxic filamentous cyanobacteria, occur during the warm season and in nutrient-rich water masses. These blooms produce a high

0091-3286/2012/\$25.00 @ 2012 SPIE 
load of organic matter, and they cause an increase of water turbidity and oxygen depletion thus creating an imbalanced functioning of the water system. ${ }^{11}$ Following the Water Framework Directive (2000/60/EC), in a number of countries chl $a$ is used as the first indicator for water quality assessment.

Inflow water from tributary rivers is the main source of colored dissolved organic matter (CDOM, also known as yellow substance), which can be measured with optical instruments in the coastal areas. ${ }^{12,13} \mathrm{CDOM}$ can be released by macroalgae, ${ }^{14}$ and it can be the product of biological processes caused by phytoplankton, bacteria production and grazing. ${ }^{15}$ In natural waters CDOM plays an important role because, due to its strong absorption of radiation in the ultraviolet (UV) portion of the electromagnetic spectrum, it protects phytoplankton, macroalgae and other biota from damaging UV medium wave (UVB) radiation. ${ }^{16}$ Moreover, CDOM plays an important role in the carbon cycle and in primary production processes. ${ }^{17}$ On the other hand, CDOM can reduce dissolved oxygen concentration causing the release of nutrients. ${ }^{18}$ Increased levels of CDOM can significantly reduce the amount and the quality of photosynthetically active radiation available to phytoplankton and other primary producers. ${ }^{19}$

Terrestrial and river runoff and wind-driven resuspension of water sediments lead to the increase of total suspended matter (TSM, also referred to as suspended particulate matter) in coastal areas. ${ }^{13,20}$ As a consequence, the greater water turbidity (i.e. lower transparency) determines a decrease of solar radiation transmittance through the water, thus limiting aquatic primary production. For these reasons, TSM is a key element of water quality monitoring in coastal areas $^{21}$ and, from an optical point of view, TSM primarily influences the back-scattering. ${ }^{22}$

In recent years, the major ecological issue in the Baltic Sea is eutrophication and the worsening of water quality. ${ }^{23}$ This has driven the most recent environmental objectives of government bodies such as the Helsinki Commission (HELCOM) and the European Commission (EC) that issued both the Water Framework Directive (2000/60/EC) and the Marine Strategy Framework Directive (2008/56/EC). Long-term monitoring programs are critical for detecting changes in the water environment, especially in view of the rapidly changing climate and the increasing anthropogenic activity in coastal waters, which are primarily impacted by pollution from land. Traditional field sampling methods cannot produce consistent datasets to monitor the spatial and temporal changes of water quality over large areas, whereas satellite-based remote sensing techniques are a key source of data for monitoring the ecological status of the ecosystems at global, regional, and local scales. ${ }^{12,24}$

Chl $a$, CDOM, and TSM, are known as optically active components and can be derived by satellite remote-sensing techniques. ${ }^{20,25}$ The estimation of optical in-water components is based on absorption and scattering properties. Moreover, the pure water, controls the optical properties, i.e. the absorption and attenuation by the water layers at visible and near-infrared wavelengths depend on temperature and salinity. ${ }^{22,26}$ Satellite-borne sensors, such as the sea-viewing wide field-of-view sensor (SeaWiFS), the moderate resolution imaging spectroradiometer (MODIS), and the medium resolution imaging spectrometer (MERIS) measure the radiation emanating from a water surface in the visible and near-infrared wavelengths, ${ }^{27}$ and they provide frequent acquisitions with sufficient spatial coverage. ${ }^{28}$ In particular, the products of the MERIS ocean color sensor on board the ENVISAT satellite of the European Space Agency (ESA) have been shown to be suitable for monitoring coastal waters ${ }^{29,30}$ with a medium but sufficient $300 \mathrm{~m}$ spatial resolution at nadir. Although in situ measurements of Chl $a$, CDOM, and TSM are spatially and temporally limited, ${ }^{31}$ they are complementary to satellite-based estimates and necessary as reference data for validation and comparison of different satellite products. Validation of satellite-based estimates of water quality parameters is a key issue for the implementation of remote sensing techniques to long-term water quality monitoring.

The Baltic Sea is considered as an optically complex Case 2 water basin: the optical water properties are strongly influenced by phytoplankton pigments, yellow substance, and suspended matter. ${ }^{12,32,33}$ The standard algorithms trained on open ocean Case 1 waters often fail due to the interference of CDOM for the estimation of $\operatorname{chl} a$ concentration. ${ }^{28}$ In order to increase satellite data applications for the assessment of water quality and for environmental investigations, it becomes necessary to develop processing algorithms suitable for optically complex coastal and inland waters. The objective of our work is to test five different neural networks-based (NNs) processors of MERIS data (FUB, C2R, Eutrophic, Boreal, and standard MERIS 
Level 2) to indentify the most suitable one for optically Case 2 or coastal and inland waters. Recent works have shown that algorithms based on NNs are better suited than band ratio algorithms for case 2 waters, ${ }^{34}$ and they allow the estimation of chl $a$ concentration in presence of CDOM. Most of these processors (Case 2 Regional, Boreal, Eutrophic, and FUB) are freely available as plug-ins in the Visat BEAM software developed by Brockmann Consult/ESA or are available as standard MERIS Level 2 products. These processors have already been tested in Baltic Sea regions: in the northwestern part, ${ }^{12,29}$ Skagerrak, ${ }^{35,36}$ open sea areas, ${ }^{37,38}$ and in the Baltic Sea largest lagoons, ${ }^{39,40}$ confirming the usefulness of satellite-based remote sensing for environmental monitoring and for supporting water authorities and policy makers. ${ }^{41}$ However, the applicability of MERIS processors has been poorly tested in the SE Baltic Sea, which has the highest wave exposure from the western direction and is strongly influenced by the large outflow of turbid freshwater from the lagoons. ${ }^{42}$ In this study we focus on the validation of satellite-based water quality parameters in the SE Baltic Sea coast, which were derived from MERIS data by applying the different processors. Validation has been carried out by comparison with in situ measurements. We also tested the effect of environmental factors on the outcome of validation. Our results provide key information for the choice of the most suitable processor for monitoring water quality in the coastal regions of the SE Baltic Sea with MERIS data. This study is a valuable addition to existing results and confirms satellite remote sensing to be an advanced tool, in addition to traditional field sampling techniques, for an accurate assessment of water quality parameters over large areas.

\section{Materials and Methods}

\subsection{Study Area}

The SE Baltic Sea includes the coastal waters of Lithuania and partly of the Kaliningrad region. The coast of the Lithuanian Baltic Sea is exposed to any wind westerly direction, with a wind fetch exceeding $200 \mathrm{~km} .{ }^{43}$ The permanent influence of SW and SE winds, waves, and water currents produces a hydrodynamically active environment with no oxygen deficiency. Generally, surface salinity is in the range of 7 to 8 PSU, whereas near the mouth of the Curonian Lagoon salinity decreases to values, which approximate those of freshwater systems, and the salinity gradient can extend for tens of kilometers out into the sea. ${ }^{44-46}$ The plume area is strongly affected by the hypereutrophic lagoon waters: ${ }^{47}$ highly productive waters, rich in dissolved organic matter and suspended particles, which reduces light penetration into the deeper water layers. ${ }^{45}$ The water temperature regime in the study area exhibits the typical boreal pattern, with the highest temperatures $\left(15 \pm 3.3^{\circ} \mathrm{C}\right.$; mean \pm standard deviation) in July and August and the lowest ones $\left(1.3 \pm 0.8^{\circ} \mathrm{C}\right)$ in January and February (unpublished monitoring data, Department of Marine Research). The mean concentration of phosphates in summer is $0.22 \pm 0.16 \mu \mathrm{mol} / 1$ and the winter maximum is $2.45 \mu \mathrm{mol} / 1$, whereas the concentration of total phosphorus in summer ranges from 0.20 to $4.81 \mu \mathrm{mol} / \mathrm{l}$, and the winter maximum is $3.55 \mu \mathrm{mol} / \mathrm{l}$. The mean concentration of nitrates in summer is $1.13 \pm 0.72 \mu \mathrm{mol} / \mathrm{l}$, while in wintertime the maximum exceeds $51 \mu \mathrm{mol} / \mathrm{l}$. Total nitrogen concentration ranges from 4.64 to $164.88 \mu \mathrm{mol} / 1$ during summer, with lower concentrations in winter (up to $116 \mu \mathrm{mol} / \mathrm{l}$ ). In general, the highest concentration of nutrients is measured in the vicinity of the Curonian Lagoon outlet. ${ }^{48}$ Long-term studies of phytoplankton composition revealed that in spring diatoms and dinoflagellate species prevail, whereas in summer the dominant group is cyanobacteria, with regularly occurring blooms, mainly caused by Aphanizomenon sp. and Nodularia spumigena. ${ }^{8,9,48}$

\subsection{In situ Data}

In situ data were collected during eight field surveys carried out from May to September 2010 in the coastal waters of the SE Baltic Sea (Fig. 1). Water samples were taken from just below the sea surface with a sampling bucket. Over a period of eight days a total of 77 samples were collected and transported with ice bags to the laboratory, where they were analyzed. Water samples for 


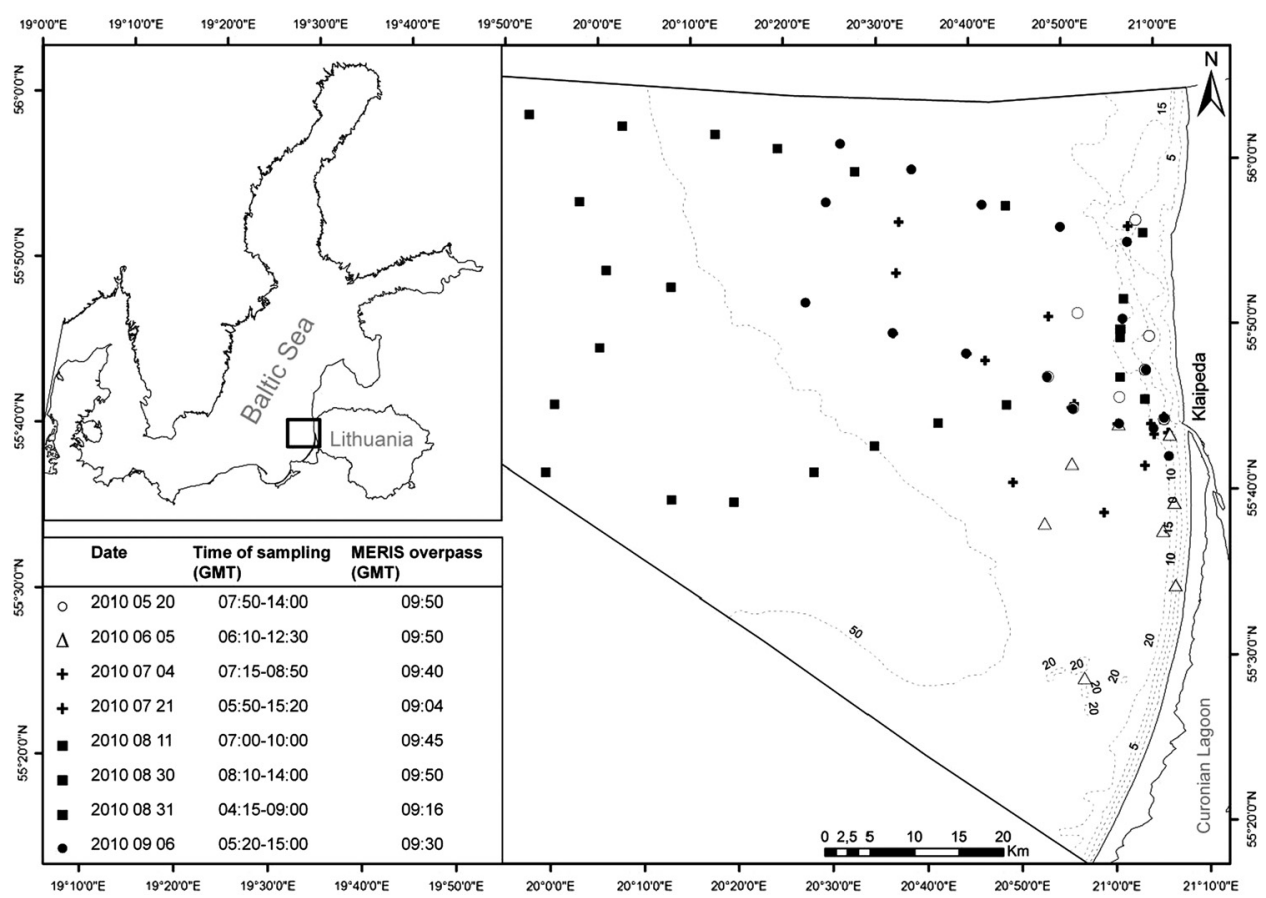

Fig. 1 The study area, sampling locations, time (GMT) of sampling and overpass of Envisat during eight surveys in 2010 over the exclusive economic zone of Lithuania in the Baltic Sea. Different sampling months are indicated by different symbols.

chl $a$ measurement were filtered through glass fiber GF/F filters with a nominal pore size $0.7 \mu \mathrm{m}$ and extracted into $90 \%$ acetone. Photosynthetic pigments were measured spectrophotometrically and estimated according to the trichromatic method, ${ }^{49,50}$ which has been already used with sampling from different areas of the Baltic Sea. ${ }^{12,29,39}$ The method is accurate in presence of other chlorophyll's (b, $c 1+c 2$ ), and it allows for the correction of its interference. ${ }^{51}$ However, the trichromatic method has some limits particularly in those environments where the degradation pigments (pheopigments) can be quantitatively relevant and can lead to an overestimation of real concentrations of $\operatorname{chl} a .^{51}$ Mantoura et al. ${ }^{51}$ stated that $10 \%$ of pheopigments can cause significant errors in the estimates of chl $a$ using method proposed by Jeffrey and Humphrey. ${ }^{49}$ Therefore in parallel the calculations of $\operatorname{chl} a$ and pheopigments were performed according to Lorenzen's ${ }^{52}$ method. The mean concentration of $\operatorname{chl} a$ calculated for the investigation period (July to September, 2010) was $13.33 \pm 22.84 \mu \mathrm{g} / \mathrm{l}$, whereas the mean concentration of pheopigments was $0.97 \pm 0.84 \mu \mathrm{g} / 1$ and comprised $7.30 \%$ of calculated chl $a$ concentration. There was no statistically significant difference $(t=0.20 ; d f=53 ; p=0.84)$ between concentration of chl $a$ estimated according to Jeffrey and Humphrey ${ }^{49}$ and Lorenzen ${ }^{52}$ methods and there was the strong linear relationship between the estimates $\left(R^{2}=0.998 ; y=0.9642 x-0.3938\right.$; $N=55$ ). These supplementary calculations confirm that the error, if present, is marginal and do not affect the results of this study.

CDOM was measured spectrophotometrically after filtration through $0.22 \mu \mathrm{m}$ membrane filters. The CDOM absorption coefficient at $440 \mathrm{~nm}\left(g_{440}\right)$ was derived according to Kirk. ${ }^{22}$ GENESYS 6 (ThermoSpectronic, USA) spectrophotometer was used for the analysis of chl $a$ and CDOM. TSM was assessed gravimetrically using the method proposed by Strickland and Parson ${ }^{53}$ and following recommendations described in Refs. 20, 54, and 55.

Water transparency was measured in situ using a standard $30 \mathrm{~cm}$ white Secchi disk. Temperature, salinity, wind speed and direction, wave conditions, sampling time, and other important observations were registered simultaneously with the water sampling. During the period covered by the field campaigns, the salinity of the surface water ranged from 0.7 to $6.9 \mathrm{PSU}$, temperature from $7.7^{\circ} \mathrm{C}$ to $21.9^{\circ} \mathrm{C}$ and Secchi depth from 0.45 to $7.20 \mathrm{~m}$. 


\subsection{Satellite Data Acquisition and Processing}

Simultaneously with the dates of the field campaigns (see Fig. 1), we acquired MERIS full resolution (FR, $300 \mathrm{~m}$ ) cloud free images. The MERIS sensors operate in the visible and near-infrared spectral range (400 to $900 \mathrm{~nm}$ ) with a wavelength configuration sensitive to the most important optically active water constituents. MERIS acquires data in 15 spectral bands of which a band $11(760 \mathrm{~nm})$ is driven to resolve spectral features of the oxygen absorption and the band $14(890 \mathrm{~nm})$ and $15(900 \mathrm{~nm})$ is using for water vapor absorption.

The Level $1 \mathrm{~b}$ images firstly were corrected to account for the difference between actual and nominal wavelengths of the solar irradiance in each channel ${ }^{56}$ with the Smile tool (1.2.101 version) of the BEAM VISAT (4.8.1) software provided by Brockmann Consult/ESA, in order to perform an irradiance correction for all bands. Later, the MERIS images were processed using four different plug-in optical processors of the BEAM VISAT software (4.8.1) in order to retrieve the water quality parameters chl $a, \mathrm{CDOM}$ and TSM. Three of the available processors were developed by the German Institute for Coastal Research GKSS ${ }^{57,58}$ : Case 2 Regional processor (C2R, 1.4.1 version), Eutrophic lakes processor (Eutrophic, 1.4.1 version) and Boreal lakes processor (Boreal, 1.4.1 version). In these processors, atmospheric correction is performed using 12 bands and reflectance values are converted into water quality parameters with different neural networks (NNs). ${ }^{57,59}$ These NNs were calibrated with simulations performed with bio-optical models and using specific inherent optical properties (IOPs) of different water types (Table 1): coastal waters (C2R), waters with high phytoplankton and chl $a$ concentrations (Eutrophic) and boreal lakes where the absorption by gelbstoff (CDOM) is high (Boreal). In particular, the C2R water processor presents a bio-optical model adapted to a wide range of IOP values. In contrast, the Eutrophic and Boreal processors share the same architecture, but the bio-optical models were optimized for extreme concentrations of $\operatorname{chl} a$ and CDOM, respectively. ${ }^{60}$

The fourth processor was developed by the German Institute for Coastal Research (GKSS) and Brockmann Consult and Freie Universität Berlin (FUB, 1.2.4 version). The FUB processor is designed for European coastal waters and uses MERIS Level 1b top-of-atmosphere radiances to retrieve the concentration of the optical water constituents. ${ }^{61}$

Generally the Lithuanian coastal waters are strongly impacted by the outflow of riverine waters and by storm processes, changing from brackish to nearly freshwater basin. Hence it is reasonable to compare different processors, such as those meant to be applied to fresh waters (i.e., Boreal and Eutrophic) and those meant to be applied to saline waters (i.e., Case 2 Regional and FUB). For all processors the default conversion factors of water quality parameters were used. ${ }^{57}$

Finally, we also obtained standard MERIS Level 2 products for the validation analysis. The NNs uses all visible bands (except for the band at $681 \mathrm{~nm}$ ). The outputs of the processing were the scattering coefficient (b), absorption by pigments $\left(a_{\mathrm{pig}}\right)$, and absorption by CDOM and detritus $\left(a_{\mathrm{CDOM}}\right)$. Concentrations of chl $a$, TSM and CDOM were calculated from the scattering and absorption coefficients based on empirical relationships. ${ }^{62,63}$ In this study we used the "algal_2" pigment index for the chl $a$, which we deemed appropriate for Case 2 coastal waters and waters rich in sediment particles and yellow substances, ${ }^{64}$ the "total_susp" for the TSM concentrations and the "yellow_subs" for the CDOM concentrations.

All the above-described processors are provided with quality flags (more about the flags in the MERIS product hand book, ${ }^{63}$ ), which give the confidence level of the quality of the retrieved parameter besides helping in the interpretation of the data. Therefore, flagged pixels were inspected and discarded or used very carefully. ${ }^{63}$

Table 1 The ranges of concentrations used to parameterize the different processors (based on Koponen et al., ${ }^{59}$ Schroeder et al. ${ }^{61}$ ) and in the standard L2 products.

\begin{tabular}{lccccc}
\hline \hline & C2R & Eutrophic & Boreal & FUB & MERIS Level 2 \\
\hline Chl a $\left(\mathrm{mg} / \mathrm{m}^{3}\right)$ & $0.003-50$ & $1-120$ & $0.5-50$ & $0.05-50$ & $0.02-43$ \\
$\operatorname{TSM}\left(\mathrm{g} / \mathrm{m}^{3}\right)$ & $0.03-50$ & $0.25-30$ & $0.1-20$ & $0.05-50$ & $0.01-51$ \\
$\operatorname{CDOM}\left(\mathrm{m}^{-1}\right)$ & $0.002-2$ & $0.1-3$ & $0.25-10$ & $0.005-1$ & $0.005-5$ \\
\hline \hline
\end{tabular}


The standard MERIS Level 2 products, after application of the Case 2 waters atmospheric correction, provide the water leaving reflectance and the accompanying flags. ${ }^{65}$ The following flags were removed from the analysis: cloud (CLOUD); ice at high aerosol load pixel (ICE HAZE); high uncorrected glint (HIGH_GLINT); uncertain normalized surface reflectance (PCD_1_13); uncertain normalized surface reflectance (PCD_16); uncertain algal pigment index 2 or bottom of atmosphere vegetation index (PCD_17), and uncertain aerosol type and optical thickness or cloud optical thickness (PCD_19). In case of FUB the flag (ATM_OUT) that identifies unrecognized reflectance data after atmospheric correction has been used for filtering. In the $\mathrm{C} 2 \mathrm{R}$ and lakes processors, pixels flagged as $\mathrm{L} 2$ are invalid if one of the seven flags are raised: top of atmosphere radiance out of valid range (RAD_ERR), land pixel (LAND), cloud or ice (CLOUD_ICE), top of standard atmosphere out of range (TOSA_OOR), water leaving radiance out of training range (OOTR), the air/water emulsion occurring at the top of ocean surface waves under high winds (WHITECAPS) and water leaving radiance reflectance out of scope (WLR_OOR). The highlighted pixels were removed from the validation procedure.

Pixels within a cloud shadow may not be flagged due to limitation of the atmospheric correction of a particular processor ${ }^{65}$ and are likely to decrease the accuracy of water quality parameters estimation. In order to limit the influence of cloud shadows, the total albedo reflectance in correspondence with each sampling station was computed for each MERIS acquisition. From this analysis we observed that in the image acquired on August 30, 2010, three stations were affected by the clouds shadow since the total values of albedo were 10 times lower than the value derived for the other stations. Hence the three stations were discarded from further analysis.

Sun glint often occurs in MERIS images when the sensor azimuth is high and solar zenith is low, and it depends on local wind fields and slicks. ${ }^{66-68}$ These sun-sensor geometric configurations occurred in the MERIS acquisition on July 4, 2010. However, the analysis of the spectral values of this image suggested they were affected by cirrus clouds rather than sun glint; $;{ }^{69}$ hence spectral data in correspondence with seven stations were removed for this date.

\subsection{Statistical Analysis}

The MERIS dataset for the validation exercise was built by extracting a window of size $3 \times 3$ pixels centered on the position (Lat/Lon) of the in situ measurements; the use of a small window rather than the single pixel reduces the influence of geo-location errors. ${ }^{70,71}$ For each $3 \times 3$ window, the proportion of flagged pixels (invalid data identified by the processor-specific flags) was computed; if more than $50 \%$ of the window pixels were flagged as invalid, the site was discarded. For the remaining windows the homogeneity of the pixels flagged as valid was tested according Bailey \& Werdell. ${ }^{71}$

Differences of water quality parameters between satellite and in situ data were quantified using different statistical error metrics: the coefficient of determination $\left(R^{2}\right)$, the mean absolute error [MAE, Eq. (1)] and the root mean square error [RMSE, Eq. (2)]:

$$
\begin{aligned}
& \text { MAE }=\frac{\sum_{i=1}^{n}\left|y_{\text {sat }}-x_{\text {in_situ }}\right|}{N} \\
& \text { RMSE }=\sqrt{\frac{\sum_{i=1}^{n}\left(y_{\text {sat }}-x_{\text {in_situ }}\right)^{2}}{N}},
\end{aligned}
$$

where $x_{\text {in_situ }}$ is the field measurement, $y_{\text {sat }}$ is the satellite estimation, $N$ is the total number of observations (valid pixels).

MAE and RMSE measure residual errors since they estimate a global difference between observed (in situ) and predicted (satellite) quantities. RMSE gives higher weight to relatively large errors, whereas MAE equally weights any differences level.

Nonlinear regression analysis (generalized additive modeling) was used to find the set of environmental factors that may explain the differences between satellite-derived and in situ measured in-water constituent concentration. The tested environmental factors were salinity, Secchi depth, distance from the coast, distance from the outlet of the lagoon, and sampling time. Before the regression analysis, the multicollinearity was tested among the environmental factors. ${ }^{72}$ The 
Secchi depth highly correlated (Pearson correlation coefficient $r>0.7$ ) with the salinity and the distance from the outlet of the lagoon, and therefore were removed from the regression. Dependent variables were transformed (e.g., by square root or logarithm) in order to fit the normal distribution. The regression analysis was performed with the "mgcv" package for $R$, version 2.13.2. The residuals of the regression models were checked for adherence to the assumption of variance equality and normality by using scatterplots (residuals versus the independent variables) and histograms. ${ }^{72}$ Spatial autocorrelation of the residuals was checked by correlogram and semivariogram using the available functions in $R$, version 2.13.2 [spline.correlog() from the package "ncf" or variog4() from the package "GeoR"].

\section{Results}

\subsection{Chlorophyll a}

The maximum in situ chlorophyll $a(\mathrm{chl} a)$ concentration of $156.18 \mathrm{mg} / \mathrm{m}^{3}$ was recorded in coastal waters in July, when a cyanobacteria bloom originated from the lagoon (Table 2). This concentration value is comparable with the maximum concentration derived by the FUB processor $\left(116.18 \mathrm{mg} / \mathrm{m}^{3}\right)$. The minimum concentration chl $a$ measured in situ and estimated by the FUB processor are also in agreement. Compared with the FUB processor, the other processors gave extremely low maximum chl $a$ values. The minimum concentration was overestimated by about four times by the lakes processors (Eutrophic and Boreal) and marginally by the C2R processor, whereas it was more than twice underestimated by the standard Level 2 product. The mean and median chl $a$ concentration derived by FUB and Boreal were the closest ones to in situ measurements, although there was relatively high variance in the data (standard deviation was twice the mean for in situ and the FUB processor). The mean and median chl $a$ concentration derived by C2R, Eutrophic and standard Level 2 were significantly underestimated.

Table 2 Descriptive statistics of water quality parameters (chl a, CDOM and TSM) measured in situ and derived from MERIS satellite data with the different processors.

\begin{tabular}{|c|c|c|c|c|c|c|c|}
\hline \multirow[b]{2}{*}{ Parameter } & \multirow[b]{2}{*}{ Statistics } & \multicolumn{6}{|c|}{ Processors } \\
\hline & & In situ & FUB & $\mathrm{C} 2 \mathrm{R}$ & Eutrophic & Boreal & Level 2 \\
\hline \multirow[t]{5}{*}{$\mathrm{Chl} a\left(\mathrm{mg} / \mathrm{m}^{3}\right)$} & minimum & 0.69 & 0.59 & 0.98 & 2.87 & 2.10 & 0.26 \\
\hline & maximum & 156.18 & 116.18 & 13.43 & 9.35 & 26.80 & 23.60 \\
\hline & mean & 12.03 & 15.41 & 9.54 & 7.30 & 16.96 & 6.68 \\
\hline & standard deviation & 20.75 & 25.66 & 2.66 & 1.47 & 5.56 & 6.75 \\
\hline & median & 4.57 & 2.56 & 10.41 & 7.66 & 17.68 & 4.51 \\
\hline \multirow[t]{5}{*}{ CDOM (1/m) } & minimum & 0.01 & 0.06 & 0.03 & 0.10 & 0.25 & 0.03 \\
\hline & maximum & 2.01 & 1.79 & 0.90 & 0.99 & 1.11 & 0.55 \\
\hline & mean & 0.42 & 0.34 & 0.19 & 0.32 & 0.37 & 0.15 \\
\hline & standard deviation & 0.40 & 0.37 & 0.21 & 0.18 & 0.17 & 0.14 \\
\hline & median & 0.33 & 0.17 & 0.09 & 0.27 & 0.29 & 0.09 \\
\hline \multirow[t]{5}{*}{$\operatorname{TSM}\left(\mathrm{g} / \mathrm{m}^{3}\right)$} & minimum & 1.05 & 0.24 & 0.22 & 0.44 & 0.21 & 0.36 \\
\hline & maximum & 32.00 & 27.05 & 7.44 & 9.53 & 5.28 & 7.91 \\
\hline & mean & 6.01 & 2.41 & 2.32 & 2.95 & 1.73 & 2.13 \\
\hline & standard deviation & 4.61 & 4.04 & 1.89 & 2.49 & 1.33 & 1.80 \\
\hline & median & 4.40 & 0.96 & 1.54 & 1.80 & 1.07 & 1.56 \\
\hline
\end{tabular}



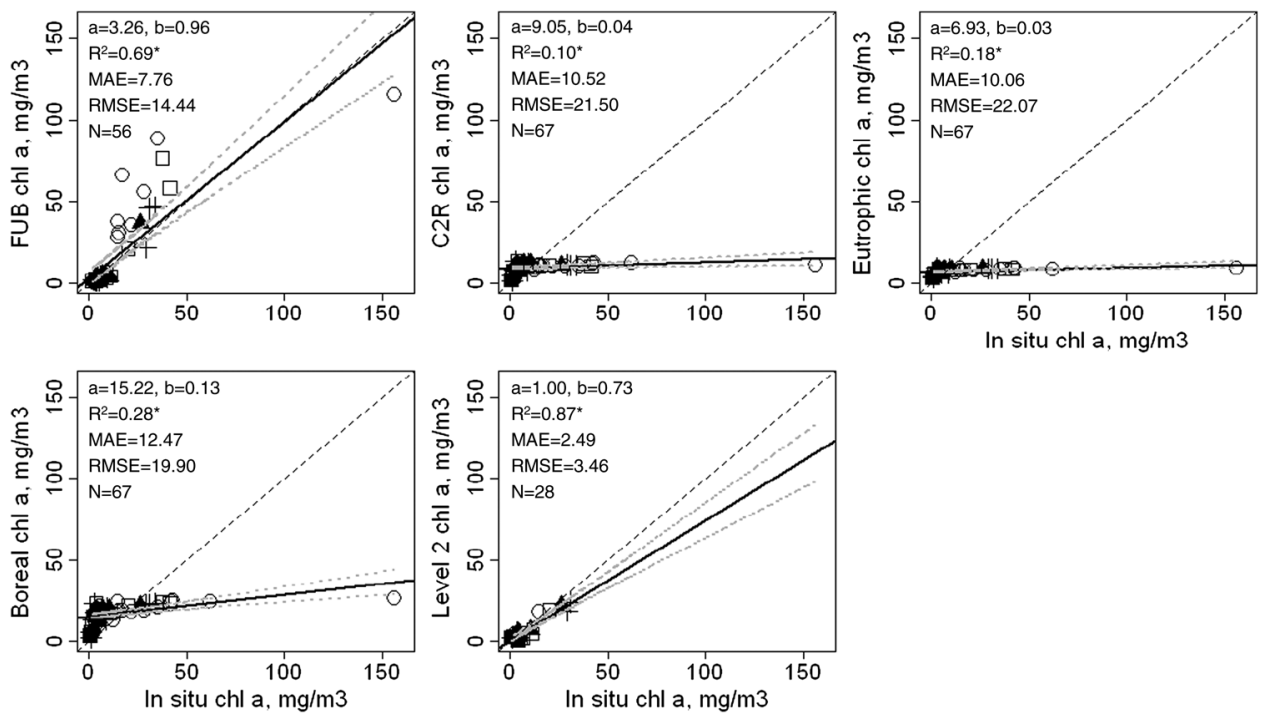

Fig. 2 Relationships between in situ measured and satellite-derived chl a by different algorithms. Black dashed line shows ideal fit 1:1, black solid line-linear trend line, grey dashed line-95\% confidence level. Statistically significant relationships are indicated in asterisks. Different intervals between the MERIS overpass and in situ measurements are indicated with different symbols: --during the overpass, $\Delta- \pm 1 \mathrm{~h}, +- \pm 2 \mathrm{~h}, \square- \pm 3 \mathrm{~h}, \mathrm{O}-$ more than $\pm 3 \mathrm{~h}$.

The best fit between in situ and estimated chl $a$ was found for the standard Level 2 processor $\left(R^{2}=0.87\right.$; MAE $\left.=2.49 \mathrm{mg} / \mathrm{m}^{3}\right)$ although more than $60 \%$ of the data was discarded due to flagged pixels, especially with high $\left(>25 \mathrm{mg} / \mathrm{m}^{3}\right) \mathrm{chl} a$ concentrations (Fig. 2). A relatively good fit was observed for the FUB processor $\left(R^{2}=0.69 ;\right.$ MAE $\left.=7.76 \mathrm{mg} / \mathrm{m}^{3}\right)$, in which case only $10 \%$ of data was discarded. In situ concentrations from 15 to $50 \mathrm{mg} / \mathrm{m}^{3}$ were slightly overestimated.

The $\mathrm{C} 2 \mathrm{R}$ and the lakes processors (Eutrophic and Boreal) explained a relatively small amount of variation in the data $\left(R^{2}=10 \%-30 \%\right)$ and produced relatively high MAE $\left(10\right.$ to $\left.12 \mathrm{mg} / \mathrm{m}^{3}\right)$. Moreover, the comparison showed an acceptable agreement only for the values of chl $a$ lower than $10 \mathrm{mg} / \mathrm{m}^{3}$, whereas above this value the satellite derived estimates were not accurate (Fig. 2).

\subsection{Colored Dissolved Organic Matter}

The maximum colored dissolved organic matter (CDOM) absorption measured in situ closely agreed only with the estimates by FUB, whereas the other algorithms underestimated it by approximately a factor of two. The mean and median CDOM absorption derived by the Boreal processor were the closest to in situ measurements, as were the estimates derived by FUB and Eutrophic (Table 2). The minimum CDOM absorption in situ was relatively similar to the derived minimum estimates by $\mathrm{C} 2 \mathrm{R}$ and standard Level 2, and marginally by the FUB processor, whereas the minimum CDOM absorption was strongly overestimated by Eutrophic and Boreal. The mean and median CDOM absorption derived by C2R and standard Level 2 were markedly underestimated.

The best fit between in situ CDOM and the satellite-derived values was found for the Boreal processor $\left(R^{2}=0.69 ; \mathrm{MAE}=0.201 / \mathrm{m}\right)$, although the processor underestimated the maximum and overestimated the minimum absorptions (Fig. 3, Table 2). Similar trends were observed with the FUB, C2R, and Eutrophic processors, which explained more than $50 \%$ of the variation and produced relatively low MAE $(0.22$ to $0.271 / \mathrm{m})$. C2R and Eutrophic performed poorly for CDOM absorption above $11 / \mathrm{m}$ showing an acceptable agreement only for lower absorption; the FUB estimates showed a good agreement with in situ data in the case of higher absorption values, although with a high variance. CDOM absorption values derived by standard Level 2 were not in agreement with in situ measurements. 

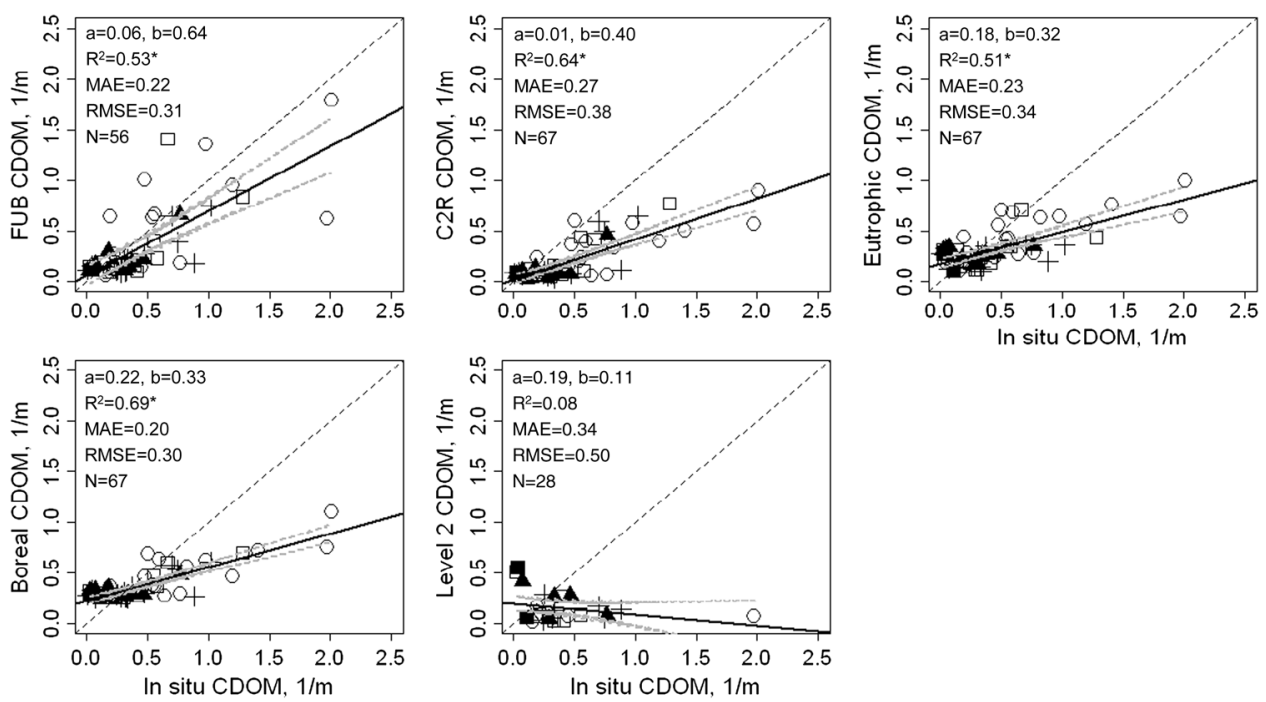

Fig. 3 Relationships between in situ measured and satellite-derived CDOM by the different processors. Black dashed line shows ideal fit 1:1, black solid line-linear trend line, grey dashed line-95\% confidence level. Statistically significant relationships are indicated in asterisks. Different intervals between the MERIS overpass and in situ measurements are indicated with different symbols: --during the overpass, $\Delta- \pm 1 \mathrm{~h}, +- \pm 2 \mathrm{~h}, \square- \pm 3 \mathrm{~h}, \mathrm{O}-$ more than $\pm 3 \mathrm{~h}$.

\subsection{Total Suspended Matter}

In situ total suspended matter (TSM) varied from 1.05 to $32 \mathrm{~g} / \mathrm{m}^{3}$ with the highest values measured on the July 21 and August 11, 2010, in the plume area of the lagoon (Table 2). The minimum TSM concentration derived by all processors was underestimated compared with in situ measurements. The maximum TSM concentration estimated with the FUB processor was the only one close to in situ data, whereas the other algorithms strongly (from three to six times) underestimated it. The mean and median TSM concentration derived by all processors was underestimated (from two to three times) compared to in situ measurements, being the Eutrophic estimates the closest ones to in situ values.

The best fit between in situ and estimated TSM was found for the FUB processor (Fig. 4), although this processor underestimated in situ measurements. The match between TSM estimated with the C2R, Eutrophic and standard Level 2 processors and in situ measurements was satisfactory: more than 50\% of explained variance and MAE in the range 3.29 to $4.05 \mathrm{~g} / \mathrm{m}^{3}$. However, TSM concentrations estimated by these processors showed an acceptable agreement only for the concentrations lower than $10 \mathrm{~g} / \mathrm{m}^{3}$. The Boreal processor produces the estimates with the poorest fit with in situ data $\left(R^{2}=0.37\right.$;AE $\left.=4.76 \mathrm{~g} / \mathrm{m}^{3}\right)$ and significantly underestimated TSM above $5 \mathrm{~g} / \mathrm{m}^{3}$.

Figure 5 shows chl $a$, CDOM and TSM distributions over the study area as retrieved from MERIS imagery acquired during one validation campaign on July 21, 2010. The highest values of the optical components were recorded close to the outlet of the lagoon. The plume area appears to be divided into two major branches most probably due to hydrometeorological conditions: the first branch is directed towards the SW and meandering more than $20 \mathrm{~km}$ from the outlet of the Curonian lagoon, whereas the second branch spread $30 \mathrm{~km}$ northward from the outlet. The patches of the water mass, where concentration of the optical components is higher than the surroundings, can be seen in the southern part up to 10 to $20 \mathrm{~km}$ off the coast. The patches most likely originated from the plume and meandered southwards due to hydrometeorological conditions. The plume area, which can be observed in the maps, is an indicator of a large enrichment of Baltic Sea coastal waters according to concentrations of all optically active components emphasizing the dynamic changes of the waters trophic status and reduction of the water quality level. 

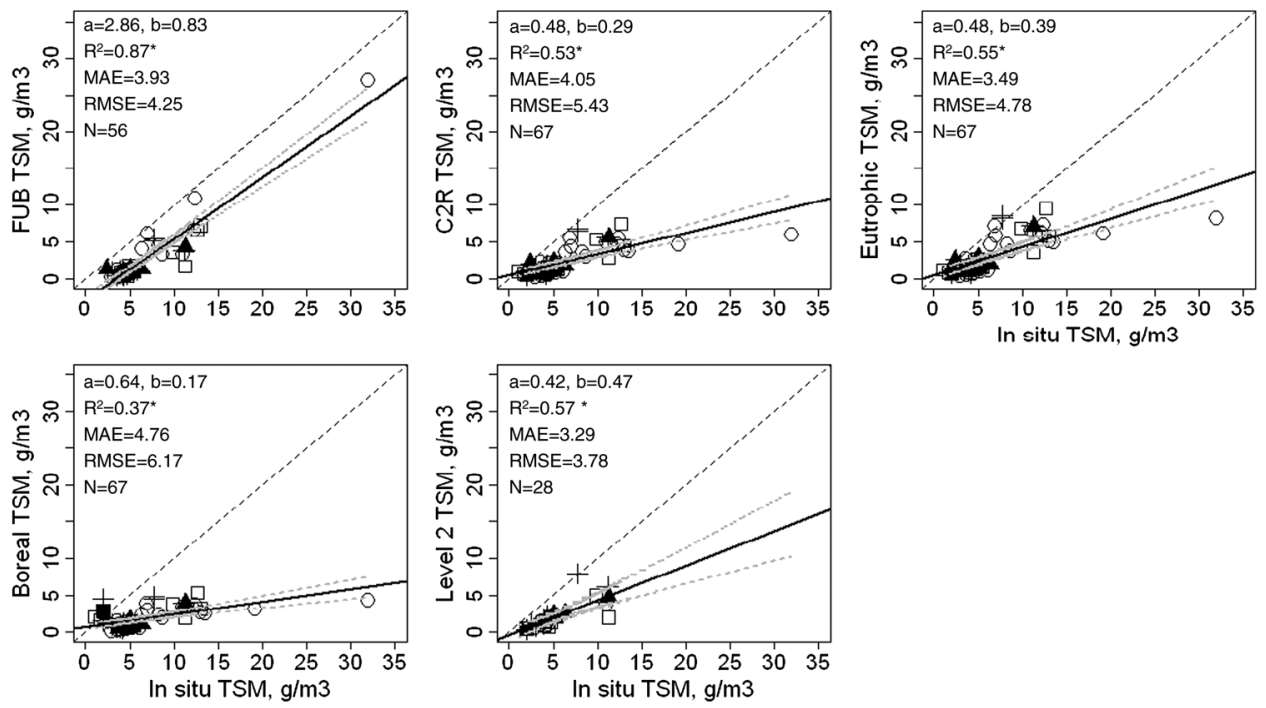

Fig. 4 Relationships between in situ measured and satellite-derived TSM by the different processors. Black dashed line shows ideal fit 1:1, black solid line-linear trend line. Statistically significant relationships indicated in bold, grey dashed line- $95 \%$ confidence level. Statistically significant relationships are indicated in asterisks. Different intervals between the MERIS overpass and in situ measurements are indicated with different symbols: «-during the overpass, $\Delta- \pm 1 \mathrm{~h}, +- \pm 2 \mathrm{~h}, \square- \pm 3 \mathrm{~h}, \mathrm{O}-$ more than $\pm 3 \mathrm{~h}$.
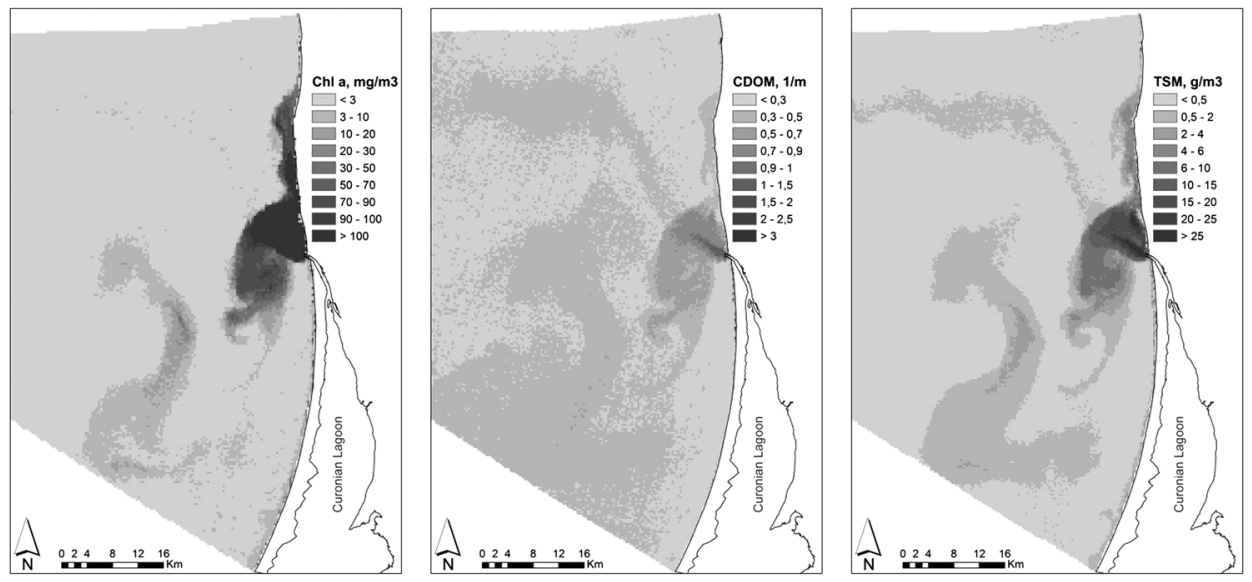

Fig. $5 \mathrm{Chl}$ a (left), CDOM (middle) and TSM (right) maps after application of different processors for MERIS images: FUB for chl $a$ and TSM and Boreal for CDOM during July 21, 2010. Maps show the outflow of eutrophic fresh water from the Curonian lagoon into the SE Baltic Sea coastal waters.

\subsection{Importance of Environmental Factors for the Validation Results}

The absolute differences between in situ chl $a$ measurements and satellite estimates were mainly explained by the Secchi depth (Table 3). The FUB processor overestimated in situ chl $a$ concentration at a Secchi depth lower than $3 \mathrm{~m}$, while at a Secchi depth greater than $3 \mathrm{~m}$ the estimates of the FUB processor were in relatively good agreement with in situ measurements (Fig. 6). The effect of Secchi depth for the absolute differences between the FUB derived and in situ measured chl $a$ concentrations explained $37 \%$ of deviance (Table 3).

More than half of deviances explained (55\% to 59\%) by the effect of the Secchi depth were found for the C2R, Eutrophic and Boreal processors. The processors strongly underestimated chl $a$ concentration at a Secchi depth below $2.5 \mathrm{~m}$. At a Secchi depth above $3 \mathrm{~m}, \mathrm{C} 2 \mathrm{R}$, Eutrophic 
Table 3 Relative importance (F value) of the explanatory variables for the validation results of water quality parameters (chl a, CDOM and TSM) among the processors, and the percentage of deviance explained by the explanatory variables. Statistically significant effects are highlighted in bold.

\begin{tabular}{|c|c|c|c|c|c|c|}
\hline & & \multicolumn{5}{|c|}{ Processors } \\
\hline & & FUB & $\mathrm{C} 2 \mathrm{R}$ & Eutrophic & Boreal & Level 2 \\
\hline \multirow[t]{7}{*}{ Chl a } & Transformation & sqrt & sqrt & sqrt & sqrt & Log \\
\hline & Number of samples & 56 & 67 & 67 & 67 & 28 \\
\hline & Explanatory variables: & & & & & \\
\hline & Secchi depth & 7.51 & 22.39 & 22.30 & 19.35 & 0.62 \\
\hline & Sampling_time & 0 & 0 & 0 & 0 & 1.87 \\
\hline & Dist_from_coast & 0 & 0 & 0 & 0 & 0 \\
\hline & Deviance explained, \% & 37 & 59 & 59 & 55 & 26 \\
\hline \multirow[t]{7}{*}{ CDOM } & Transformation & sqrt & sqrt & sqrt & sqrt & Sqrt \\
\hline & Number of samples & 56 & 67 & 67 & 67 & 28 \\
\hline & Explanatory variables: & & & & & \\
\hline & Secchi depth & 0.86 & 12.28 & 14.34 & 17.50 & 31.28 \\
\hline & Sampling_time & 0 & 1.87 & 0.04 & 0.28 & 1.34 \\
\hline & Dist_from_coast & 0 & 0 & 0 & 0 & 0 \\
\hline & Deviance explained, \% & 15 & 47 & 46 & 51 & 86 \\
\hline \multirow[t]{7}{*}{ TSM } & Transformation & $\log$ & $\log$ & sqrt & $\log$ & Log \\
\hline & Number of samples & 56 & 67 & 67 & 67 & 28 \\
\hline & Explanatory variables: & & & & & \\
\hline & Secchi depth & 3.14 & 13.99 & 20.18 & 17.30 & 2.85 \\
\hline & Sampling_time & 0 & 0 & 0.64 & 0 & 0 \\
\hline & Dist_from_coast & 0 & 0 & 0 & 0 & 0 \\
\hline & Deviance explained, \% & 7 & 49 & 59 & 53 & 13 \\
\hline
\end{tabular}

and Boreal slightly overestimated in situ measurements (Fig. 6). A relatively weak effect of Secchi depth was found for the standard Level 2 (26\% deviance explained).

The effect of the sampling time was found only for the standard Level 2 processor, although it was not statistically significant (Table 3). However, the difference between in situ and satellite derived estimates by all processors were relatively high $3 \mathrm{~h}$ before and $4 \mathrm{~h}$ after the satellite overpass (Fig. 6), that occurred over the investigation area approximately at 9:00 to 9:50 (GTM).

The absolute difference between in situ CDOM measurements and the satellite estimates were mainly explained by the Secchi depth, followed by the sampling time, for all processor except FUB (Table 3). The values of deviance explained varied from $15 \%$ for the FUB processor to $86 \%$ for the standard Level 2 processor. The difference for all processors with in situ CDOM measurements highly varied at a Secchi depth lower than $4.5 \mathrm{~m}$ (Fig. 6), whereas more accurate estimates were obtained at a Secchi depth greater than $4.5 \mathrm{~m}$. The C2R processor and the standard Level 2 strongly underestimated CDOM absorptions at a Secchi depth below $2 \mathrm{~m}$.

The effect of sampling time on CDOM showed a pattern similar to the case of chl $a$ (Fig. 6) with significant differences between in situ CDOM measurements and satellite estimates $2 \mathrm{~h}$ before and after satellite overpass. However, the difference between in situ CDOM 

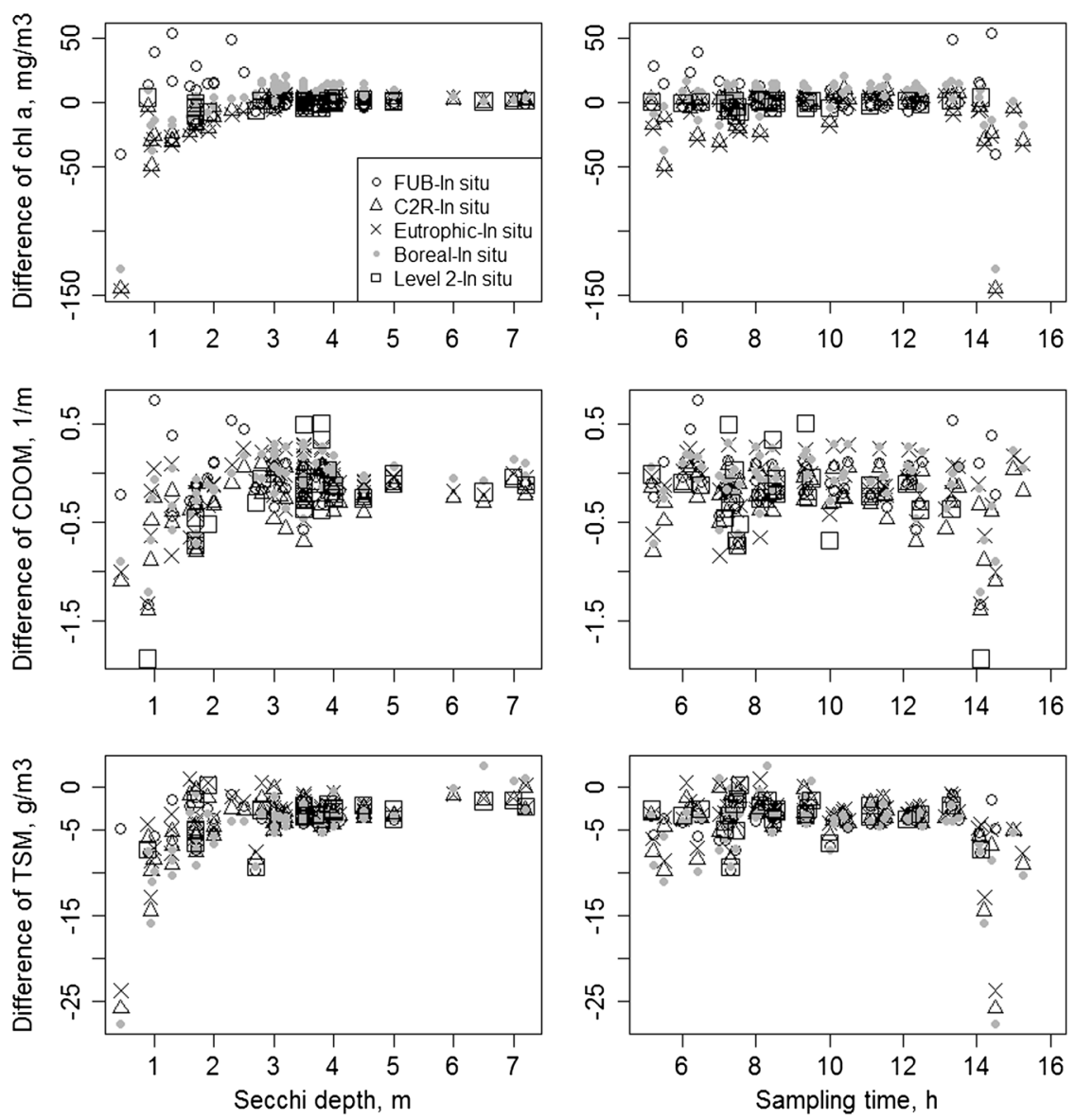

Fig. 6 Scatterplots of differences, between the in situ measured water quality parameters (chl a, CDOM and TSM) and derived by different processors, Secchi depth, and sampling time.

measurements and the standard Level 2 estimates were relatively high even during the time of satellite overpass.

The absolute differences between in situ TSM measurements and satellite estimates were mainly explained by the Secchi depth (Table 3). The values of deviance explained varied from $7 \%$ for the FUB processor to 59\% for the Eutrophic processor. Secchi depth had a relatively small effect on the accuracy of the FUB processor and the standard Level 2 estimates. Overall, all processors underestimated the TSM concentration: the greater difference were observed at a Secchi depth lower than $3 \mathrm{~m}$, while at a Secchi depth above $3 \mathrm{~m}$ the differences were relatively smaller. An effect of sampling time was observed only for the Eutrophic processor, although it was not statistically significant (Table 3 ). However, the differences for all processors were relatively high $3 \mathrm{~h}$ before and $4 \mathrm{~h}$ after the satellite overpass (Fig. 6).

\section{Discussion}

In general, results from the FUB processor showed a good agreement with in situ measurements for all optically active components, especially chl $a$ and TSM (Figs. 2 and 4). Our results highlighted that the FUB processor with the sufficient confidence level was useful in the offshore area and in the plume area, where relatively high concentration of pigments and other in-water constituents occurred. The same processor was tested in Skagerrak ${ }^{35}$ and in the Himmerfjärden Bay, northwestern part of the Baltic Sea. ${ }^{12}$ Similarly to our results, investigations in Skagerrak demonstrated the ability of the FUB processor to predict well both chl $a$ and TSM concentrations. Kratzer et al. ${ }^{12}$ found that the FUB processor performed very well in the open Baltic Sea. The promising results from the validation of estimates derived by the FUB processor over 
different parts of the Baltic Sea suggest that it could be used as a common tool for monitoring the spatial distribution of water quality parameters in the Baltic Sea.

The C2R, Eutrophic, and Boreal processors strongly underestimated chl $a$ concentration, showing obvious threshold within 10 to $27 \mathrm{mg} / \mathrm{m}^{3}$. The $\mathrm{C} 2 \mathrm{R}$ processor was tested in the NW part of the Baltic Sea and contradictory results were obtained. ${ }^{29}$ In the open Sea, chl $a$ was overestimated by the processor [mean normalized bias $(\mathrm{MNB})=118.7 \%$; root mean square $(\mathrm{RMS})=141.6 \%$, whereas in the coastal waters chl $a$ was underestimated $(\mathrm{RMS}=-68.2 \%$; $\mathrm{MNB}=63.3 \%$ ). According to the results obtained in the northern Curonian lagoon, ${ }^{39}$ the strong underestimation of chl $a$, particularly during cyanobacteria bloom, could be due to uncorrected C2R-derived remote-sensing reflectance $\left(R_{\mathrm{rS}}\right)$ at red/near-infrared wavelengths. It is known, that the $\mathrm{C} 2 \mathrm{R}$ processor is unable to capture the typical peak of remote-sensing reflectance $\left(R_{\mathrm{rs}}\right)$ around $700 \mathrm{~nm}$, due to a combination of high backscattering, exponentially increasing absorption by water molecules and low absorption by CDOM and phytoplankton. ${ }^{73}$ The results obtained by Giardino et al. ${ }^{39}$ confirmed the remarks regarding the plume area, where higher chl $a$ concentration is often measured. However, in our study we directly validated water quality parameters and the validation of remote sensing reflectance $\left(R_{\mathrm{rs}}\right)$ will be addressed in the future. The best agreement between in situ and satellite-derived CDOM absorption was found for the Boreal processor (Fig. 3), in which the neural network was trained with data from the boreal forest region with high absorption of gelbstoff. ${ }^{57,59}$ Moreover, CDOM absorption derived by the Eutrophic processor was also in moderate agreement with in situ measurements suggesting that the algorithms developed for fresh waters can be used also for the brackish waters of the Baltic Sea. The estimates of CDOM absorption derived by the FUB and C2R processors were comparable to in situ measurements as well, demonstrating the ability of these processors to accurately predict CDOM. According to Ref. 39, the $\mathrm{C} 2 \mathrm{R}$ processor gave CDOM in the same ranges as in situ measurements in the highly eutrophic Curonian Lagoon waters. TSM concentration derived by the $\mathrm{C} 2 \mathrm{R}$, Eutrophic and Boreal processors were in moderate agreement with in situ measurements showing some underestimation (see Fig. 4). In summary, the C2R, Boreal and Eutrophic processors provided ranges of CDOM comparable to in situ measurements and could be used for the CDOM mapping over the lacustrine and brackish coastal waters.

The validation of the standard MERIS Level 2 products showed, that the fit between satellite derived and in situ measured chl $a$ was in exceptionally good agreement (Fig. 2), although maximum chl $a$ predictions were below $23 \mathrm{mg} / \mathrm{m}^{3}$. This was the effect of the high proportion $(>60 \%)$ of flagged pixels that were discarded from the analysis. In order to compare the relevance of predicted water quality parameters with other processors, we tested the goodness of fit with a reduced number of observations $(N=26)$ for all processors (Table 4). The accuracy of Chl $a$ estimates derived by the FUB processor were comparable to those derived by the standard Level $2\left(R^{2}=0.84 ;\right.$ MAE $\left.=3.59 \mathrm{mg} / \mathrm{m}^{3}\right)$, although with the higher prediction error. It should be mentioned, that in this study CDOM absorption was estimated in terms of yellow substance, whereas CDOM absorption by the standard Level 2 product is the sum of yellow substance and detritus in terms of the bleached particle (BP) absorption. ${ }^{37}$ This difference might explain the observed disagreement. Ohde et al. ${ }^{37}$ and Siegel et al. ${ }^{38}$ showed that absorption by BP can contribute to the total absorption by both CDOM and BP by about $15 \%$ in the clear open Baltic Sea and up to $25 \%$ in the coastal waters. Thus, it should be taken into account and tested in the near future in order to make the final conclusion regarding the prediction of CDOM absorption by the standard Level 2 product.

All processors predicted TSM exceptionally well in the similar confidence level range (Table 4). After the reduction of the number of observations used for the analysis, the best fit between the TSM measurements in situ and derived by algorithm was found for the Eutrophic processor $\left(R^{2}=0.69 ; \mathrm{MAE}=2.99 \mathrm{~g} / \mathrm{m}^{3}\right)$, whereas with the full data set the best agreement was found with the FUB processor. The fit between standard Level 2 estimates and in situ was an intermediate $\left(R^{2}=0.54 ; \mathrm{MAE}=3.42 \mathrm{~g} / \mathrm{m}^{3}\right)$ and the predictions by the processor were below $12 \mathrm{~g} / \mathrm{m}^{3}$ concentrations.

The large amount of data in the standard Level 2 products is usually dropped due to quality flags and therefore the extreme concentrations, which are important for the assessment of water quality, are meant to be overlooked. According to Stelzer et al., ${ }^{74}$ the ESA Case 2 Regional C2R processor is one option for overcoming this problem, as well as the Boreal and the Eutrophic 
Table 4 Explained variance $\left(R^{2}\right)$, regression coefficients (slope and intercept), mean absolute error (MAE), and root mean squared error (RMSE) of different processors for water quality parameters (chl a, CDOM and TSM) from reduced number of samples $(N=26)$.

\begin{tabular}{|c|c|c|c|c|c|}
\hline & & & $\mathrm{Chl} a\left[\mathrm{mg} / \mathrm{m}^{3}\right]$ & CDOM $[1 / \mathrm{m}]$ & TSM $\left[\mathrm{g} / \mathrm{m}^{3}\right]$ \\
\hline \multirow[t]{20}{*}{ Processors } & FUB & $R^{2}$ & 0.84 & 0.55 & 0.62 \\
\hline & & $\begin{array}{l}\text { Slope } \\
\text { and } \\
\text { intercept }\end{array}$ & $1.29 \times$ Chl $_{\text {in situ }}-2.89$ & $0.34 \times \mathrm{CDOM}_{\text {in situ }}+0.07$ & $0.38 \times \mathrm{TSM}_{\text {in situ }}-0.71$ \\
\hline & & MAE & 3.59 & 0.23 & 4.20 \\
\hline & & RMSE & 5.32 & 0.34 & 4.61 \\
\hline & $\mathrm{C} 2 \mathrm{R}$ & $R^{2}$ & 0.17 & 0.54 & 0.68 \\
\hline & & $\begin{array}{l}\text { Slope } \\
\text { and } \\
\text { intercept }\end{array}$ & $0.10 \times \mathrm{Chl}_{\text {in situ }}+8.51$ & $0.34 \times \mathrm{CDOM}_{\text {in situ }}+0.03$ & $0.53 \times \mathrm{TSM}_{\text {in situ }}-0.86$ \\
\hline & & MAE & 6.31 & 0.26 & 3.50 \\
\hline & & RMSE & 7.94 & 0.37 & 3.87 \\
\hline & Eutrophic & $R^{2}$ & 0.30 & 0.58 & 0.69 \\
\hline & & $\begin{array}{c}\text { Slope } \\
\text { and } \\
\text { intercept }\end{array}$ & $0.07 \times \mathrm{Ch}_{\text {in situ }}+6.69$ & $0.21 \times \mathrm{CDOM}_{\text {in situ }}+0.17$ & $0.70 \times \mathrm{TSM}_{\text {in situ }}-1.23$ \\
\hline & & MAE & 5.61 & 0.22 & 2.99 \\
\hline & & RMSE & 8.01 & 0.35 & 3.33 \\
\hline & Boreal & $R^{2}$ & 0.46 & 0.68 & 0.65 \\
\hline & & $\begin{array}{c}\text { Slope } \\
\text { and } \\
\text { intercept }\end{array}$ & $0.36 \times \mathrm{Chl}_{\text {in situ }}+13.68$ & $0.26 \times \mathrm{CDOM}_{\text {in situ }}+0.23$ & $0.37 \times \mathrm{TSM}_{\text {in situ }}-0.57$ \\
\hline & & MAE & 9.82 & 0.18 & 4.17 \\
\hline & & RMSE & 10.52 & 0.30 & 4.58 \\
\hline & Level 2 & $R^{2}$ & 0.86 & 0.09 & 0.54 \\
\hline & & $\begin{array}{c}\text { Slope } \\
\text { and } \\
\text { intercept }\end{array}$ & $0.74 \times \mathrm{Ch}_{\text {in situ }}+0.94$ & $-0.12 \times \mathrm{CDOM}_{\text {insitu }}+0.21$ & $0.47 \times \mathrm{TSM}_{\text {in situ }}-0.38$ \\
\hline & & MAE & 2.59 & 0.36 & 3.42 \\
\hline & & RMSE & 3.58 & 0.52 & 3.90 \\
\hline
\end{tabular}

processors. For example, only $13 \%$ of the pixels were flagged in this study by these processors, whereas FUB flagged $27 \%$ of all measurements. Nevertheless, the standard Level 2 products were broadly investigated over the whole Baltic Sea basin soon after the launch of Envisat satellite: in the NW part of the Baltic Sea, ${ }^{12}$ Skagerrak, ${ }^{35,36}$ in the SW part and in the open Baltic Sea,${ }^{37}$ and in the Vistula lagoon. ${ }^{40}$ These studies demonstrated the highly variable results of the comparison between the in situ and satellite derived values. The studies performed in the open sea waters of northern Baltic Sea showed that the standard Level 2 processor overestimated chl $a$ by about $59 \%$, and TSM (in terms of suspended particulate matter) by about $28 \%$, and underestimated CDOM by about $81 \% .^{12}$ Sørensen et al. ${ }^{35}$ described the validation results from the northern part of Skagerrak with additional measurements in Kattegat. In situ measured $\operatorname{chl} a$ explained $86 \%$ of the variance in standard Level 2 (RMS $\left.=1.17 \mathrm{mg} / \mathrm{m}^{3}\right)$, whereas the in situ measured TSM explained $71 \%$ of the variance (RMS $=0.30 \mathrm{~g} / \mathrm{m}^{3}$ ). The results were presumable, since conversion factors used in the empirical relationships of processor were determined in Skagerrak and later included in the second reprocessing of the MERIS data. ${ }^{35,36}$ The results highlighted the advantage of regional conversion factors to be implemented into the 
models of processors. In the western part of the Baltic including open sea and discharge areas of the Oder River in the Pomeranian Bay, the standard Level 2 products underestimated in situ measurements. ${ }^{37}$ According to Ref. 40, the correlation between in-water constituents measured in situ and derived by the standard Level 2 products was weak in the Vistula Lagoon. In summary, one can state that the standard MERIS Level 2 products are useful for monitoring $\operatorname{chl} a$ and TSM over the Baltic Sea.

The differences between in situ measurements and satellite-derived water quality parameters could be related to water types, especially coastal waters influenced by eutrophic lacustrine waters, that differ in their specific inherent optical properties (IOPs), ${ }^{75}$ IOPs used for the parameterization of the MERIS Neural Network algorithms that differ from those measured in the region of interest, aerosol types within the coastal region challenging the atmospheric correction process, ${ }^{76}$ and adjacency effect of the coast. ${ }^{29}$ As noted, the SE Baltic Sea coastal waters are extremely influenced by fresh, productive, highly eutrophic Curonian lagoon waters. The later waters constantly mix with brackish coastal water masses causing very rapid changes in the concentration of chl $a, \mathrm{CDOM}$ and TSM, herewith certainly causing an increase of absorption by pigments and CDOM, and scattering by suspended material, i.e. rapid changes in the IOPs. However, re-parameterization of the MERIS NNs algorithms was outside the scope of this study owing to the scarcity IOPs and radiometric measurements in the study area. Instead, we focused on the analysis of environmental and sampling conditions that may cause the observed differences between satellite-derived and in situ measured concentrations of in-water constituents.

From the nonlinear regression analysis we found that Secchi depth was the mainly important factor, whereas the effects of distance from the coast and sampling time were not statistically significant. The Secchi depth strongly correlated $(r>0.7)$ with salinity, chl $a$, CDOM, and TSM concentrations, and distance from the outlet of the lagoon being a proxy of rapidly changing IOPs within the investigated region. In general, the absolute differences between satellite-derived and in situ measured values increased with the decrease of the Secchi depth (Fig. 6). Low differences (close to zero) were between 4 and $7 \mathrm{~m}$ of the Secchi depth, where water salinity ranged 6 to 7 PSU, which is typical for the Lithuanian Baltic Sea coastal waters. ${ }^{1,9,77}$

The data presented here showed, that the $\mathrm{C} 2 \mathrm{R}$, Boreal, and Eutrophic processors strongly underestimated in situ chl $a$ concentrations over the sampling locations with reduced Secchi depth, whereas the FUB algorithm overestimated chl $a$ concentrations. As mentioned before, $\mathrm{C} 2 \mathrm{R}$ was unable to capture the typical peak of remote sensing reflectance $\left(R_{\mathrm{rs}}\right)$ around $700 \mathrm{~nm}$, especially during intensive production of phytoplankton. ${ }^{39,73}$ This is highly probable in the coastal areas impacted by productive waters of the Curonian lagoon, where drastic changes of IOPs occur. Similarly, the greatest differences of CDOM and TSM concentrations given by all processors were found within the locations with reduced Secchi depth, suggesting the need of in situ measurements of IOPs in very mixed waters.

Kratzer et al. ${ }^{12}$ emphasized the difficulty to get a temporal match between the satellite overpass and in situ data due to the frequent cloud cover over the Baltic Sea. Moreover, in situ data are usually taken in a wider time frame than the satellite overpass due to design of sampling locations and usually extra measurements of other water parameters (e.g. nutrients, primary production, plankton community structure). For this reason we tested the effect of sampling time on the differences between in situ measurements and the satellite-derived estimates. In the regression analysis, the sampling time was not a statistically significant factor, whereas the Secchi depth explained most of the variance in the estimated differences. However, there was an evident match of in situ measurements and satellite-based estimates within 1 to $2 \mathrm{~h}$ before the overpass of satellite to approximately 2 to $3 \mathrm{~h}$ after it (Fig. 6). These results may give useful information for future validation analysis, since the appropriate time for sampling differed among the water quality parameters.

\section{Conclusions}

In this study we determined the most potential processors, which could be used for the assessment of the water quality parameters in the SE Baltic Sea waters. The FUB and standard Level 2 processors were able to derive chlorophyll $a$ concentration in the optically heterogeneous SE Baltic Sea waters. The Boreal processor, trained on data from the freshwater environment, was 
appropriate to derive CDOM with sufficient accuracy in the brackish waters. The concentration of TSM was accurately predicted by the satellite data after application of the FUB processor. This study confirmed that the MERIS images could be beneficial for mapping ecological situation of the SE Baltic Sea coastal waters showing the changes of water quality. The nonlinear regression analysis highlighted the plume area as crucial for the prediction of water quality parameters by satellite remote-sensing techniques. The highly dynamic turbid, productive, rich in dissolved humic substances and reduced salinity plume area caused relatively high difference between satellite derived and in situ measured constituent concentrations. However, the FUB processor was able to predict the maximum concentrations of both chl $a$ and TSM in the plume area. In the coastal waters not impacted by the lacustrine lagoon waters the estimates of both the FUB and the standard Level 2 processors were in the sufficient range with in situ chl $a$ and TSM measurements. The CDOM estimates derived by the Boreal processor were comparable to in situ measurements in the same type of waters. The evident match between in situ measurements and satellite-based estimates was observed when field measurements were acquired 1 to $2 \mathrm{~h}$ before to approximately 2 to $4 \mathrm{~h}$ after the satellite overpass. The appropriate time frame for sampling differed to some extent among the water constituents. Radiometric measurements and validation of inherent optical properties remain not quantified yet and should be tested in the near future in order to improve the use satellite-based remote sensing techniques for large-scale observation of water quality parameters.

\section{Acknowledgments}

Satellite data was provided via Category-1 user (ID 7835, IP D. Vaiciute) and by Brockmann Consult/ESA as part of the MarCOAST 2 project. This study was partially supported by the EU FP7 project MEECE (Marine Ecosystem Evolution in a Changing Environment, 212085), by a Norwegian financial mechanism and the Republic of Lithuania project EEE (a system for the sustainable management of Lithuanian marine resources using novel surveillance, modeling tools and an ecosystem approach, LT0047). The authors thank Daniela Stroppiana, Claudia Giardino, and Erica Matta (CNR-IREA, Italy), and Marco Bartoli (Parma University, Italy) for their comments on the manuscript. We thank Kerstin Stelzer, Jasmin Geißler, Dr. Carsten Brockmann (Brockmann Consult, Germany), associate professor Susanne Kratzer and her team from Stockholm University (Sweden) for the opportunity to get the experience in the field of optical remote sensing. We are very grateful to Erikas Visakavičius, Evelina Grinienè and Viktorija Savickyte (Klaipeda University, Lithuania) for their assistance during the fieldwork. We are grateful to professor Victor V. Klemas for the English revision of manuscript. Comments and suggestions from the two anonymous reviewers were greatly appreciated. Thanks are due to Renata Pilkaitytė (Klaipeda University, Lithuania) for her enthusiastic support.

\section{References}

1. H. Storch and A. Omstedt, "Introduction and summary," in Assessment of Climate Change for the Baltic Sea Basin, H.-J.Bolle, M. Menenti, and I. Rasool, Eds., pp. 473, SpringerVerlag, Berlin Heidelberg (2008).

2. C. Rönnberg and E. Bonsdorff, "Baltic Sea eutrophication: area-specific ecological consequences," Hydrobiologia 514(1-3), 227-241 (2004), http://dx.doi.org/10.1023/B:HYDR .0000019238.84989.7f.

3. P. Coble et al., "Colored dissolved organic matter in the coastal ocean. An optical tool for coastal zone environmental assessment and management," Oceanography 17(2), 51-59 (2004), http://dx.doi.org/10.5670/oceanog.

4. L. Malmgren and L. Brydsten, "Sedimentation of river-transported particles in the Ore estuary, northern Sweden," Hydrobiologia 235/236(1), 59-69 (1992), http://dx.doi.org/ 10.1007/BF00026200.

5. J. L. Largier, "Estuarine fronts: How important are they?" Estuaries 16(1), 1-11 (1993), http://dx.doi.org/10.2307/1352760.

6. N. Wasmund and S. Uhlig, "Phytoplankton trends in the Baltic Sea," ICES J. Mar. Sci. 60(2), 177-186 (2003), http://dx.doi.org/10.1016/S1054-3139(02)00280-1. 
Vaičiūtè, Bresciani, and Bučas: Validation of MERIS bio-optical products with in situ data...

7. K. Kononen, "Dynamics of the toxic cyanobacterial blooms in the Baltic Sea," Finn. Mar. Res. 261, 3-36 (1992).

8. N. Wasmund et al., "Trophic status of the south-eastern Baltic Sea: a comparison of coastal and open areas," Estuar. Coast. Shelf Sci. 53(6), 849-864 (2001), http://dx.doi.org/10.1006/ ecss.2001.0828.

9. Z. R. Gasiūnaite et al., "Seasonality of coastal phytoplankton in the Baltic Sea: influence of salinity and eutrophication," Estuar. Coast. Shelf Sci. 65(1-2), 239-252 (2005), http://dx .doi.org/10.1016/j.ecss.2005.05.018.

10. N. Wasmund et al., "Long-term trends in phytoplankton composition in the western and central Baltic Sea," J. Mar. Syst. 87(2), 145-159 (2011), http://dx.doi.org/10.1016/j .jmarsys.2011.03.010.

11. T. S. Bianchi et al., "Cyanobacterial blooms in the Baltic Sea: natural or human induced?" Limnol. Oceanogr. 45(3), 716-726 (2000), http://dx.doi.org/10.4319/lo.2000.45.3.0716.

12. S. Kratzer, C. Brockmann, and G. Moore, "Using MERIS full resolution data to monitor coastal waters - a case study from Himmerfjärden, a fjord-like bay in the northwestern Baltic Sea," Rem. Sens. Environ. 112(5), 2284-2300 (2008), http://dx.doi.org/10.1016/j .rse.2007.10.006.

13. S. Kratzer, K. Ebert, and K. Sørensen, "Monitoring the bio-optical state of the Baltic Sea ecosystem with remote sensing and autonomous in situ techniques," Part VIII in The Baltic Sea Basin, J.Harff, S. Björck, and P. Hoth, Eds., p. 449, Springer, New York (2011).

14. C. J. Hulatt et al., "Exudation and decomposition of chromophoric dissolved organic matter (CDOM) from some temperate macroalgae," Estuar. Coast. Shelf Sci. 84(1), 147-153 (2009), http://dx.doi.org/10.1016/j.ecss.2009.06.014.

15. P. G. Coble, "Marine optical biogeochemistry: the chemistry of ocean color," Chem. Rev. 107(2), 402-418 (2007), http://dx.doi.org/10.1021/cr050350+.

16. N. V. Blough and S. A. Green, "Spectroscopic characterization and remote sensing of nonliving organic matter" in The Role Of Non-Living Organic Matter in The Earth's Carbon Cycle, R. G.Zepp and C. Sonntag, Eds., pp. 23-45, John Wiley and Sons, Chichester, England (1995).

17. M. A. Moran and R. G. Zepp, "Role of photoreactions in the formation of biologically labile compounds from dissolved organic matter," Limnol. Oceanogr. 42(6), 1307-1316 (1997), http://dx.doi.org/10.4319/lo.1997.42.6.1307.

18. K. L. Bushaw et al., "Photochemical release of biologically available nitrogen from aquatic dissolved organic matter," Nature 381(6581), 404-407 (1996), http://dx.doi.org/10.1038/ $381404 \mathrm{a} 0$.

19. R. R. Bidigare, M. E. Ondrusek, and J. M. Brooks, "Influence of the Orinoco River outflow on distributions of algal pigments in the Caribbean Sea," J. Geophys. Res. 98(C2), 2259-2269 (1993), http://dx.doi.org/10.1029/92JC02762.

20. S. Kratzer and P. Tett, "Using bio-optics to investigate the extent of coastal waters a Swedish case study," Hydrobiologia 629(1), 169-186 (2009), http://dx.doi.org/10.1007/s10750-009 -9769-x.

21. G. Premazzi et al., "Methods in Limnology," Part I in Manual for Monitoring European Lakes Using Remote Sensing Techniques, T.Lindell, D. Piersson, G. Premazzi, and E. Zilioli, Eds., p. 164, Office for Official Publications of the European Communities, Luxembourg (1999).

22. J. T. O. Kirk, Light and Photosynthesis in Aquatic Ecosystems, 3rd ed., Cambridge University Press, Cambridge (2011).

23. HELCOM, "The HELCOM Baltic Sea action plan," available from: http://www.helcom.fi/ press_office/news_helcom/en_GB/BSAP_full/(5 August 2012).

24. T. Kutser et al., "Monitoring cyanobacteria blooms by satellite remote sensing," Estuar. Coast. Shelf Sci. 67(1-2), 303-312 (2006), http://dx.doi.org/10.1016/j.ecss.2005 .11.024.

25. A. G. Dekker et al., "Remote sensing for inland water quality detection and monitoring: state-of-the-art application in Friesland waters" in GIS and Remote Sensing Technology in Land and Water Management, A.Van Dijk and M. G. Bos, Eds., pp. 17-38, Kluwer Academic Publishers, Netherlands (2001). 
26. W. S. Pegau, D. Gray, and J. R. V. Zaneveld, "Absorption and attenuation of visible and near-infrared light in water: dependence on temperature and salinity," Appl. Opt. 36(24), 6035-6046 (1997), http://dx.doi.org/10.1364/AO.36.006035.

27. D. G. Capone and A. Subramaniam, "Seeing microbes from space," ASM News 71(4), 179-186 (2005).

28. A. Reinart and T. Kutser, "Comparison of different satellite sensors in detecting cyanobacterial bloom events in the Baltic Sea," Rem. Sens. Environ. 102(1-2), 74-85 (2006), http:// dx.doi.org/10.1016/j.rse.2006.02.013.

29. S. Kratzer and C. Vinterhav, "Improvement of MERIS level 2 products in Baltic Sea coastal areas by applying the Improved Contrast between Ocean and Land processor (ICOL) - data analysis and validation," Oceanologia 52(2), 211-236 (2010).

30. R. Doerffer, K. Sørensen, and J. Aiken, "MERIS potential for coastal zone application," Inter. J. Rem. Sens. 20(9), 1809-1818 (1999), http://dx.doi.org/10.1080/ 014311699212498.

31. P. Bierman et al., "A review of methods for analysis spatial and temporal patterns in coastal water quality," Ecol. Indicat. 11(1), 103-114 (2011), http://dx.doi.org/10.1016/j.ecolind .2009.11.001.

32. A. Morel and L. Prieur, "Analysis of variations of ocean colour," Limnol. Oceanogr. 22(4), 709-722 (1977), http://dx.doi.org/10.4319/lo.1977.22.4.0709.

33. C. D. Mobley, Light and Water-Radiative Transfer in Natural Waters, p. 529, Academic Press, San Diego (1994).

34. H. Schiller and R. Doerffer, "Neural network for emulation of an inverse modeloperational derivation of case II water properties form MERIS data," Int. J. Rem. Sens. 20(9), 1735-1746 (1999).

35. K. Sørensen et al., "Validation of MERIS products in the Skagerrak," in Proc. of the 2nd MERIS/(A)ATSR User Workshop, H.Lacoste and L. Ouwehand, Eds., ESA publication SP-666, Noordwijk, The Netherlands (2008).

36. K. Sørensen, E. Aas, and J. Høkedal, "Validation of MERIS water products and bio-optical relations in the Skagerrak," Int. J. Rem. Sens. 28(3-4), 555-568 (2007), http://dx.doi.org/10 $.1080 / 01431160600815566$.

37. T. Ohde, H. Siegel, and M. Gerth, "Validation of MERIS Level-2 products in the Baltic Sea, the Namibian coast and the Atlantic Ocean," Int J. Rem. Sens. 28(3-4), 609-624 (2007), http://dx.doi.org/10.1080/01431160600972961.

38. H. Siegel, T. Ohde, and M. Gerth, "Preliminary MERIS-validation results for the Baltic Sea," in Proc. of Envisat-Validation Workshop, ESA publication SP-531, Frascati, Italy (2003).

39. C. Giardino et al., "In situ measurements and satellite remote sensing of case 2 waters: first results from the Curonian Lagoon," Oceanologia 52(2), 197-210 (2010).

40. M. Kruk et al., "Uniseasonal dynamics of main water quality parameters in Vistula Lagoon extracted from Envisat/MERIS geophysical products and in situ measurements," in Proc. Hyperspectral 2010 Workshop, Frascati, Italy, H.Lacoste-Francis, Ed., ESA publication SP-683, Noordwijk, The Netherlands (2010).

41. M. Bresciani et al., "Assessing remotely sensed chlorophyll-a for the implementation of the Water Framework Directive in European Perialpine lakes," Sci. Total Environ. 409(17), 3083-3091 (2011), http://dx.doi.org/10.1016/j.scitotenv.2011.05.001.

42. D. Daunys et al., "Typology and classification of ecological status of Lithuanian coastal and transitional waters: an update of existing system, procurement of services for the institutional building for the Nemunas River basin management," Tech. Rep. Transit. Fac. Proj. No. 2004/016-925-04-06 (2007).

43. S. Olenin, D. Daunys, and J. Leinikki, "Biodiversity study and mapping of marine habitats in the vicinity of the Būtingè Oil Terminal, Lithuanian coastal zone, Baltic Sea," Joint Finnish-Lithuanian project report, p. 30, Coastal Research and Planning Institute, Klaipeda University, Klaipèda (2003).

44. J. Dubra and V. Dubra, "Influence of sewage waters from the Kurshiu Marios Lagoon to the Baltic Sea," in Proc. of the 19th Conf. of the Baltic Oceanographers, Sopot, Poland, Vol. 2, pp. 771-779 (1994). 
Vaičiūtè, Bresciani, and Bučas: Validation of MERIS bio-optical products with in situ data...

45. I. Olenina and S. Olenin, "Environmental problems of the South-Eastern Coast and the Curonian Lagoon," in Baltic Coastal Ecosystems. Structure, Function and Coastal Management, E.Schernewski and U. Schiewer, Eds., pp. 149-156, Springer-Verlag, Berlin, Heidelberg, New York (2002).

46. S. Olenin and D. Daunys, "Coastal typology based on benthic biotope and community data: the Lithuanian case study," in Baltic Sea Typology, G.Schernewski and M. Wielgat, Eds., Coastline Reports 4, pp. 65-83, Leiden, The Netherlands (2004).

47. R. Pilkaityte and A. Razinkovas, "Seasonal changes in phytoplankton composition and nutrient limitation in a shallow Baltic lagoon," Boreal Environ. Res. 12(5), 551-559 (2007).

48. I. Olenina and R. Kavolyte, "Phytoplankton, chlorophyll a and environmental conditions in the southeastern coastal zone of the Baltic Sea," in Proc. of the 13th Symp. of the Baltic Marine Biologists, A.Andrushaitis, Eds., Jūrmala, Latvia, pp. 53-61 (1996).

49. S. W. Jeffrey and G. F. Humphrey, "New spectrophotometric equations for determining chlorophyll a,b,c1 and c2 in higher plants, algae and natural phytoplankton," Biochem. Physiol. Pfl. 167, 191-194 (1975).

50. T. R. Parsons, Y. Maita, and C. M. Lalli, A Manual of Chemical and Biological Methods for Seawater Analysis, Pergamon Press, New York (1984).

51. R. F. C. Mantoura, "Comparison between spectrophotometric, fluorometric and HPLC methods for chlorophyll analysis," Chapter 14 in Phytoplankton Pigments in Oceanography: Guidelines to Modern Methods (Monographs on Oceanographic Methodology), S. W.Jeffrey, R. F. C. Mantoura, and S. W. Wright, Eds., p. 661, UNESCO Publishing, Paris (2005).

52. C. J. Lorenzen, "Determination of chlorophyll and pheopigments: spectrophotometric equations," Limnol. Oceanogr. 12(2), 343-346 (1967), http://dx.doi.org/10.4319/lo.1967 .12.2.0343.

53. J. H. D. Strickland and T. R. Parsons, A Practical Handbook of Seawater Analysis, 2nd ed., Series of Bulletin of the Fisheries Research Board of Canada, Vol. 167, p. 310, University of California, Canada (1972).

54. R. Doerffer, "Protocols for the validation of MERIS water products," Doc. No. PO-TNMEL-GS-0043, p. 42, GKSS/MERIS-ESL, ESA (2002).

55. S. Kratzer, B. Håkansson, and C. Sahlin, "Assessing Secchi and photic zone depth in the Baltic Sea from satellite data," Ambio 32(8), 577-585 (2003).

56. N. Fomferra and C. Brockmann, "The BEAM project web page," Brockmann Consult, Hamburg, Germany, available from: http://www.brockmann-consult.de/beam/ (17 January 2006).

57. R. Doerffer and H. Schiller, "MERIS lake water algorithm for BEAM ATBD," GKSS Research Center, Geesthacht, Germany (2008).

58. R. Doerffer and H. Schiller, "MERIS Regional Coastal and Lake Case 2 Water ProjectAtmospheric Correction ATBD," Version 1.0 18, GKSS Research Center, Geesthacht, Germany (2008).

59. S. Koponen et al., "Development of MERIS lake water algorithms," Validation Report, available from: http://www.brockmann-consult.de/beam-wiki/download/attachments/ 8355860/MERIS_LAKES_Validation_report.pdf (28 May 2008).

60. A. Ruiz-Verdù et al., "Development of MERIS lake water algorithms: validation results from Europe," in Proc. 2nd MERIS/(A)ATSR User Workshop, ESA/ESRIN, H. Lacoste and L. Ouwehand, Eds., Frascati, Italy, ESA publication SP-666, Noordwijk, The Netherlands (2008).

61. T. Schroeder, M. Schaale, and J. Fischer, "Retrieval of atmospheric and oceanic properties from MERIS measurements: a new Case-2 water processor for BEAM," Int. J. Rem. Sens. 28(24), 5627-5632 (2007), http://dx.doi.org/10.1080/01431160701601774.

62. R. Doerffer, "MERIS Case I validation," in Proc. of the Second Working Meeting on MERIS and AATSR Calibration and Geophysical Validation (MAVT-2006), ESA publication SP-615, Frascati, Italy (2006).

63. ESA, "MERIS Product Handbook," Issue 2.1, October 24, p. 130, available at: http:// dearth.esa.int/pub/ESA_DOC/ENVISAT/MERIS/meris.ProductHandbook.2_1.pdf (5 May 2006). 
64. R. Doerffer and H. Schiller, "Neural network for retrieval of concentrations of water constituents with the possibility to detecting exceptional out of scope spectra," in IEEE 2000 International Geoscience and Remote Sensing Symp., Vol. 2, pp. 714-717, Honolulu Hawaii (24-28 July 2000).

65. C. Brockmann, "Limitations of the application of the MERIS atmospheric correction," in Proc. of the Second Working Meeting on MERIS and AATSR Calibration and Geophysical validation (MAVT-2006), ESA publication SP-615, Frascati, Italy (20-24 March 2006).

66. E. J. Hochberg, S. Andrefouet, and M. R. Tyler, "Sea surface correction of high spatial resolution IKONOS images to improve bottom mapping in near-shore environments," IEEE Trans. Geosci. Rem. Sens. 41(7), 1724-1729 (2003), http://dx.doi.org/10.1109/ TGRS.2003.815408.

67. R. Doerffer, "Atmosphere and glint correction project, algorithm theoretical basis document (ATBD)," Version 1.0, pp. 45, (2008).

68. T. Kutser, E. Vahtmäe, and J. Praks, "A sun glint correction method for hyperspectral imagery containing areas with non-negligible water leaving NIR signal," Rem. Sens. Environ. 113(10), 2267-2274 (2009), http://dx.doi.org/10.1016/j.rse.2009.06.016.

69. M. Pepe et al., "Snow cover monitoring in Alpine regions using ENVISAT optical data," Int. J. Rem. Sens. 26(21), 4661-4667 (2005), http://dx.doi.org/10.1080/01431160500206635.

70. F. S. Patt, "Navigation algorithms for the SeaWiFS mission," SeaWiFS Postlaunch Technical Report Series, S. B.Hooker and E. R. Firestone, Eds., Vol. 16, NASA Technical Memorandum 2002-206892, NASA Goddard Space Flight Center, Greenbelt, MD (2002).

71. W. S. Bailey and J. P. Werdell, "A multi-sensor approach for the on-orbit validation of ocean color satellite data products," Rem. Sens. Environ. 102(1-2), 12-23 (2006), http://dx.doi .org/10.1016/j.rse.2006.01.015.

72. A. F. Zuur, E. N. Ieno, and G. M. Smith, Analysing Ecological Data, Series of Statistics for Biology and Health, M.Gail, K. Krickeberg, J. M. Samet, A. Tsiatis, and W. Wong, Eds., p. 672, Springer, New York (2007).

73. T. Kutser, "Passive optical remote sensing of cyanobacteria and other intense phytoplankton blooms in coastal and inland waters," Int. J. Rem. Sens. 30(17), 4401-4425 (2009), http://dx .doi.org/10.1080/01431160802562305.

74. K. Stelzer et al., "MERIS validation with respect to operational monitoring needs in the North and Baltic Sea," in Proc. of the 2nd MERIS/(A)ATSR User Workshop, ESA SP-666, Frascati, Italy (2008).

75. K. L. Carder et al., "Marine humic and fulvic acids: their effects on remote sensing of ocean chlorophyll," Limnol. Oceanogr. 34(1), 68-81 (1989), http://dx.doi.org/10.4319/lo.1989.34 .1 .0068 .

76. G. Zibordi et al., "Cross-site consistent in situ measurements for satellite ocean color applications: the BiOMaP radiometric dataset," Rem. Sens. Environ. 115(8), 2104-2115 (2011), http://dx.doi.org/10.1016/j.rse.2011.04.013.

77. R. Žaromskis, Oceans, Seas and Estuaries, p. 293, Vilnius, Lithuanian (1996).

Biographies and photographs of the authors are not available. 